особенности течения раннего врожденного сифилиса и выделены наиболее значимые клинико-лабораторные показатели, позволяющие оптимизироватьдиагностику данной патологии. Всего по теме «Сифилис» на кафедре защищены 1 докторская и 16 кандидатских диссертаций. Теме мочеполовых инфекций посвящены 3 кандидатских диссертации (Ю.Ю. Винник, М.В. Шапран, В.В. Волошин).

Общие итоги научной работы кафедры: защищены 6 докторских и 43 кандидатских диссертаций, опубликованы 17 монографий, получены 15 патентов на изобретения.

В настоящее время кафедра дерматовенерологии с курсом косметологии и ПО КрасГМУ - это единый комлектив, в котором опытные преподаватели и клиницисты работают вместе с талантливой молодёжью. Кафедра не только переняла старые традиции российской школы дерматовенерологов,

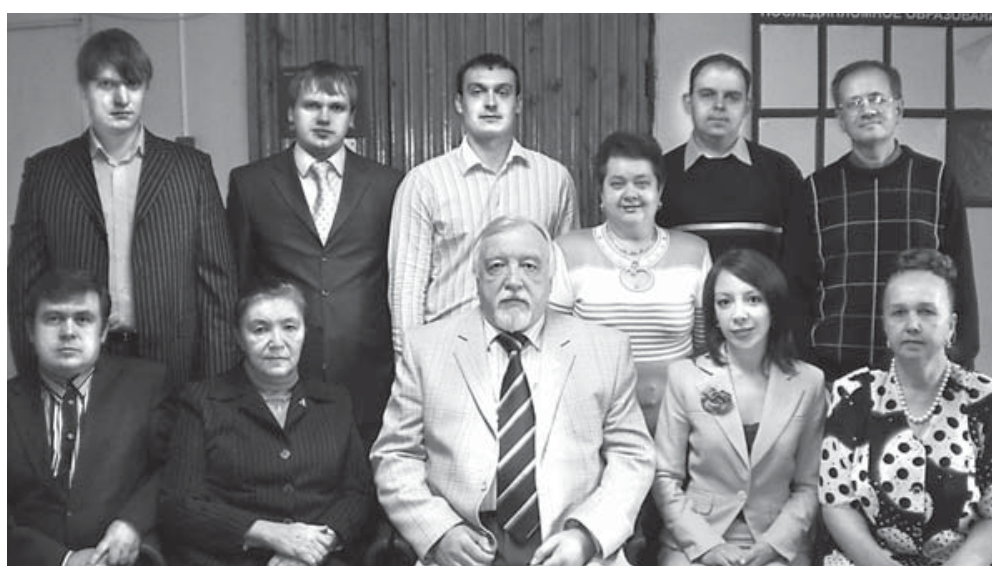

Колмектив кафеgры gерматовенерологии с курсом косметологии ПО КрасГМУ (2013 г.) заложенные её основателями, но и успешно развивает новые направления научной, педагогической и практической деятельности.

\title{
Сведения об авторах
}

Прохоренков Виктор Иванович - gоктор меgицинских наук, профессор завеяующий кафеярой gерматовенерологии с курсом косметологии и ПО ГБОУ ВПО Красноярский государственный меgищинский университет имени проф. В. Ф. Войно-Ясенецкого МЗ РФ.

Agрес:660022, г. Красноярск, ул. Партизана Железняка, g. 1; тел. 8(391) 2114101; e-mail:kras_derma@mail.ru.

Гузей Татьяна Николаевна - кандиgат меgицинских наук, доцент кафеgры gерматовенерологии с курсом косметологии и ПО ГБОУ ВПО Красноярский госуgарственный меgицинский университет имени проф. В. Ф. Войно-Ясенецкого МЗ РФ.

Agрес:660022, г. Красноярск, ул. Партизана Железняка, g. 1; тел. 8(391) 2114101; e-mail:kras_derma@mail.ru.

Карачева Юлия Викторовна - gоктор меgицинских наук, профессор кафеgры gерматовенерологии с курсом косметологии и ПО ГБОУ ВПО Красноярский госуgарственный меgицинский университет имени проф. В. Ф. Войно-Ясенецкого МЗ РФ.

Agрес:660022, г. Красноярск, ул. Партизана Железняка, g. 1; тел. 8(391) 2114101; e-mail:kras_derma@mail.ru.

Яковлева Татьяна Александровна - кандиgат меgицинских наук, уоцент кафеgры gерматовенерологии с курсом косметологии и ПО ГБОУ ВПО Красноярский госуяарственный меgицинский университет имени проф. В. Ф. Войно-Ясенецкого MЗ РФ.

Agpес: 660022, г. Красноярск, ул. Партизана Железняка, g. 1; тел. 8(391) 2114101 e-mail: kras_derma@mail.ru.

Бекетов Александр Михайлович - кандияат меgицинских наук, gоцент кафеgры gерматовенерологии с курсом косметологии и ПО ГБОУ ВПО Красноярский госуgарственный меgицинский университет имени проф. В. Ф. Войно-Ясенецкого МЗ РФ.

Agpec: 660022, г. Красноярск, ул. Партизана Железняка, g. 1; тел. 8(391)2114101; e-mail: kras_derma@mail.ru.

Гасич Нина Андреевна - канgugат меgицинских наук, ассистент кафеgры gерматовенерологии с курсом косметологии и ПО ГБОУ ВПО Красноярский госуgарственный меgицинский университет имени проф. В. Ф. Войно-Ясенецкого МЗ РФ.

Agрес: 660022, г. Красноярск, ул. Партизана Железняка, g. 1; тел. 8(391) 2114101; e-mail: kras_derma@mail.ru.

Мисенко Амитрий Николаевич - кандияат меgицинских наук, ассистент кафеgры gерматовенерологии с курсом косметологии и ПОГБОУ ВПО Красноярский госуgарственный меgицинский университет имени проф. В. Ф. Войно-Ясенецкого МЗ РФ.

Agpec: 660022, г. Красноярск, ул. Партизана Железняка, g. 1; тел. 8(391) 2114101; e-mail:kras_derma@mail.ru.

\section{Аннотации и рецензии}

( ) ТИХОМИРОВ А. $\Lambda$.

УАК 618.145-002.18-092-036-07(049.32)

\section{РЕЦЕНЗИЯ НА МОНОГРАФИЮ А. И. ПАШОВА, В. Б. ЦХАЙ, Ю. А. АЫХНО «ПРОЛИФЕРАТИВНЫЕ ПРОЦЕССЫ ЭНАОМЕТРИЯ. ПАТОГЕНЕЗ, ПРОГНОЗИРОВАНИЕ, РАННЯЯ АИАГНОСТИКА»}

\author{
А. $\Lambda$. Тихомиров
}

ГБОУ ВПО Московский государственный медико-стоматологический университет имени А. И. Евдокимова Министерства зАравоохранения РФ, ректор - А. М. н., проф. О. О. Янушевич; кафедра акушерства и гинекологии лечебного факультета, зав. - А. М. Н., проф. И. Б. Манухин.

Резюме. Преgставлена монография, посвященная изучению прооксияантного и антиоксияантного статуса, гуморально-клеточных факторов регулящии метаболизма, роли НАА и НАА(Ф)-зависимых ферментов в механизмах развития пролиферативных процессов эндометрия - и в реализаци канцерогенного gействия онкоиняуцирующих агентов. Авторский опыт, комбинированного лечения агонистами гонаgолиберина и внутриматочной левоноргестрел-рилизинг системой сложной атипической гиперплазии и рака эндометрия, защищен патентом Российской Феgерации. Отмечена актуальность и несомненный интерес gля меgищинской науки и практического зgравоохранения.

Ключевые слова: пролиферация, эндометрий, рак, метаболизм, gиагностика, прогноз. 


\title{
REVIEW OF THE MONOGRAPH A. I. PASHOVA, V. B. TSKHAI, YU. A. DYKHNO “ENDOME-
} TRIAL PROLIFERATIVE PROCESSES. PATHOGENESIS, PREDICTING, EARLY DIAGNOSIS ${ }^{\prime \prime}$

\author{
A. L. Tikhomirov
}

Moscow State University of Medicine and Dentistry named after A. I. Evdokimov

\begin{abstract}
The presented monograph is devoted to the study of pro-oxidant and antioxidant status, humoral, cell factors of regulating the metabolism, the role of NAD and NAD $(P)$ - dependent enzymes in the mechanisms of endometrial proliferative processes and the realization of a carcinogenic effect onco-inducing agents. Author's experience of combined treatment of GnRH agonists and levonorgestrel-releasing intrauterine system of complex atypical hyperplasia and endometrial cancer is protected by a patent of the Russian Federation. Was marked the urgency and undeniable interest for medical science and health care .

Key words: proliferation, endometrium, cancer , metabolism, diagnosis, prognosis
\end{abstract}

Монография посвящена одной из актуальной задач современной гинекологии и патологической физиологии, затрагивающей глубокое и многостороннее рассмотрение пролиферативных процессов эндометрия, гиперплазия которого в ряде случаев лежит в фундаменте неопластической трансформации клеток. Впервые было доказано, что у пациенток с раком эндометрия отмечается повышение активности глутатионовых антиоксидантных ферментов, обеспечивающих не только восстановление продуктов пероксидации, но и способствующих клеточной пролиферации, характерной дмя данного патологического процесса. Выявлено, что показатели прооксидантного и антиоксидантного статуса, а также их соотношения являются диагностическими критериями наличия рака эндометрия. Аоказано, что отличительной особенностью злокачественного опухолевого роста в теле матки является достоверное повышение концентраций продуктов перекисного окисления липидов и снижение активности антиоксидантных ферментов в крови по мере нарастания тяжести заболевания и уменьшения степени дифференцировки опухоли. Впервые обнаружена утрата чувствительности клеток опухоли к гормональным влияниям и выявлены гуморально-клеточные факторы регуляции метаболизма, определяющие развитие высоко- или низкодифференцированного рака эндометрия.

В результате проведенного исследования авторами монографии получены новые научные данные, расширяющие и углубляющие фундаментальные представления о патогенезе пролиферативных процессов эндометрия, что способствует совершенствованию детальной диагностики и патогенетической терапии. Впервые показана роль НАА(Ф)-зависимых ферментов в механизмах развития пролиферативных процессов эндометрия и в реализации канцерогенного действия онкоиндуцирующих агентов и в их эффректах через образование свободных радикалов и нарушение антиоксидантного баланса. Установлена диагностическая значимость инструментальных методов исследования в Аифференциальной диагностике гиперпластических процессов эндометрия и различных морфологических вариантов рака тела матки. По результатам исследования получены метаболические характеристики ткани эндометрия, установлены факторы гуморальной регуляции тканевого метаболизма ферментов и предложена схема патогенеза метаболических механизмов формирования рака эндометрия, отражающая взаимодействия гормональной, про - и антиоксидантной системы в регуляции метаболических процессов, формирующих противоопухолевый иммунитет.

Отдельной главой монографии, представлен опыт авторов комбинированного лечения агонистами гонадолиберина и внутриматочной левоноргестрел-рилизинг системой сложной атипической гиперплазии и рака эндометрия, защищенный патентом Российской Федерации.

Книга предназначена Аля врачей онкогинекологов, акушеров-гинекологов, патофизиологов, иммунологов, студентов медицинских вузов и врачей других специальностей, интересующихся данной проблемой.

\section{Сведения об авторах}

Тихомиров Александр Аеонияович - gоктор меgицинских наук, профессор кафеgры акушерства и гинекологии лечебного факультета Московского государственного меgико-стоматологического университета имени А. И. Евgокимова МЗ РФ, заслуженный врач $Р Ф$, лауреат премии Правительства РФ в области наукии техники.

Agpec: 127473, г. Москва, ул. Аелегатская, g. 20/1: тел. 8(499) 1782831; е-таil: tikhomiroval@yandex.ru.

\section{Юбилейные даты}

УАK 614.23:617.5

\section{К 75-АЕТИЮ СО АНЯ РОЖАЕНИЯ ПЕААГОГА И ХИРУРГА НИКОААЯ АМИТРИЕВИЧА ТОМНЮКА}

\section{TO THE 75TH ANNIVERSARY OF TEACHER AND SURGEON - NIKOLAI DMITRIEVICH TOMNYUK}

27 декабря 2013 года исполняется 75 лет доценту кафедры и клиники хирургических болезней имени профессора Юрия Моисеевича Аубенского Красноярского государственного медицинского университета Томнюку Николаю Амитриевичу.
Николай Амитриевич родился в 1938 году в семье рабочего, в селе Старый-Косов Косовского района Ивано-Франковской области (УССР). 1946 год - начало учёбы в первом классе Старо-Косовской восьмилетней школы. В 1950 году 